\author{
Naida-Michal Brandl \\ E-mail: mbrandl@ffzg.hr \\ University of Zagreb, Faculty of Humanities and Social Sciences \\ Ivana Lučića 3 HR - 10000 Zagreb \\ Zrinka Podhraški Čizmek \\ E-mail: zri.pod1@gmail.com \\ $\mathrm{PhD}$ researcher in Maritime History \\ Livadićeva 26 HR - 10000 Zagreb
}

\title{
Codex Diplomaticus Maritimus Croatiae/Croatian Diplomatic Maritime Codex and the Croatian Maritime Regesta, vol. 4: Emerging project
}

\begin{abstract}
This paper presents an outline and announces the continuation of the Codex Diplomaticus Maritimus Croatiae (Croatian Diplomatic Maritime Codex), consisting of a total of 100,000 documents on Croatia's presence in the Adriatic and the Mediterranean. Nikola Čolak had started this project in 1956 in Zadar and was developing it for the next 40 years, exploring all the relevant archives on both coasts of the Adriatic that were relevant for not only Croatian history but for everyone else participating in this trade (Italians, Jews, and many others). After the $3^{\text {rd }}$ volume of the Croatian Maritime Regesta was published in 2017, two historians decided to continue, in collaboration with other Croatian and foreign researchers, the publication of the aforementioned series by publishing the $4^{\text {th }}$ volume of this series. The project introduces, as the innovation to the original project, the use of modern technologies related to the processing of digitized data as to allow everyone free access to hitherto unpublished archival sources in regesto as well as in extenso, depending on the importance of the document.
\end{abstract}

Key words: Codex Diplomaticus Maritimus Croatiae/Croatian Diplomatic Maritime Codex; Croatian Maritime Regesta, $18^{\text {th }}$ century; the Adriatic; the Mediterranean; Levante; Ponente; Trade; Sources; Dalmatia; Ottoman-Venetian relations; Ships; Ports; Jewish-Cristian contacts; Pilgrimages; Multireligiosity; Multiculturalism.

\section{Introduction}

The fourth volume of the Croatian Maritime Regesta by Nikola Čolak, with ca. 4,000 documents from the Archivio di Stato di Venezia relating to the Croatian Adriatic coast of the $18^{\text {th }}$ century, is being published 40 years after having been transcribed by the author in Venice and Padua (between 1973 and 1977). 
We started our co-operation regarding the continuation of publication of these very valuable documents in the beginning of 2014, during Zrinka's work on the edition of the $3^{\text {rd }}$ volume, when we realized how great the role of the Jews was in these documents. Interested and intrigued, we started analyzing the first two volumes (that included ca. 12,000 documents) in search of scientific confirmation of what we had just hypothesized. Indeed, the first statistical results were surprising, not only the figures and names of members of Jewish communities active in the $18^{\text {th }}$ century inside and outside the Adriatic (which was confirmed by over 400 documents), but also a whole multicultural and multireligious world in their essence. The results of these first researches were presented in 2016 in Venice at the International Conference on The Birth and Evolution of the Venetian Ghetto: 1516-1797, by the work "Jewish Merchants between two Adriatic Coasts in the $18^{\text {th }}$ Century", which attracted great attention from the organizers and participants at the conference alike as it was about completely new sources regarding Jewish communities in the Adriatic.

Using unpublished documents for the third volume that Zrinka had been preparing for many years, we analyzed nearly 16,000 documents; the results of this research confirmed additionally the diversity and richness of Jewish communities and their role in complex trade networks not only within the Adriatic but also in relation to other realities in eastern Mediterranean, western Mediterranean and, of course, northern seas and the countries around them. The results of these analyses were presented at several international conferences from different perspectives (maritime routes and types of goods of specific family/families and/or trade networks, with an emphasis on the Adriatic and its internal trade and, on the other hand, on the Mediterranean as well as the out-of-Mediterranean trade).

Even today, there is a huge void in the Croatian historiography regarding the systematic publication of primary sources on the maritime history of Croatian lands; the field where Nikola Čolak has remained a pioneer. His project on publishing a total of 20 volumes of the Croatian Maritime Regesta (in part in regesto and in part in extenso, depending on the importance of the documents) requires a joint venture, not just because of the quantity of documents - a total of about 100,000 entries, but also for further analysis that should further deepen the different aspects of the said material.

\section{The Adriatic: The intersection of different cultures}

In that sense, the wealth of Jewish presence in the documents, that clearly shows a very dynamic Adriatic world, which in the $18^{\text {th }}$ century encompassed the unbelievably wide variety and presence of a series of communities that traded and lived on two shores of the Adriatic, is one more element that has brought us together to continue the printing of a series of Croatian Maritime Regesta in co-operation with other scholars presenting new documents that will serve further processing by historians, linguists and, in our case, scholars in Judaic and Maritime studies. 
The $18^{\text {th }}$ century is a century where we see that, apart from peoples of the Adriatic region, a great number of French, English, Russian, Dutch and others were entering the Mare Nostrum. The sea de facto became a kind of foundry of a new world and a new way of life - these documents are the faithful image of those processes, enabling us to experience the incredible everyday life of the people at the time: sailors, passengers, captains, pilgrims, merchants, agents, pirates and corsairs, shipowners, consuls, rectors and many others.

Regarding the choice of documents for this volume of the Regesta, we followed instructions that Nikola Čolak had left in his archive. His intention was first to publish the documents of the $18^{\text {th }}$ century, primarily about navigation within the Adriatic and in the direction of the Levant. He then planned to publish documents regarding navigation in the Western Mediterranean and after that in the Atlantic for the said century. Then, the earlier centuries should have been treated since the $17^{\text {th }}$ and $16^{\text {th }}$ centuries were much better represented in the historiography so far as proposed by Čolak.

The fourth volume consists of a total of ca. 4,000 newly published documents of the $18^{\text {th }}$ century from 11 different collections from the Venetian State Archives, bringing together 50 different files, thus continuing the series of the Croatian Maritime Regesta.

As previously mentioned, the first volume of the Croatian Maritime Regesta was published in Padua in 1985 and it brought 4,890 entries from the Archivio di Stato di Venezia and the Archivio Comunale di Fano and contained various documents:

- Sources from the collection Cinque Savi alla Mercanzia, institution that was a supervisor for trade, both in the Levante and Ponente;

- A collection of Venetian consulates and letters from their consuls, general governors (Provveditori generali) and priors from Ancona, Alexandria, Durrës, Shkodër, Split, Fano;

- List of entries and departures from Ancona (the major Adriatic port, entry and exit port to the whole Mediterranean);

- Material on shipwrecks;

- Document, for the Levante and Ponente, relating to La Serenissima official affairs.

The second volume, published in Padua in 1993, contains 6,891 entries from the Archivio di Stato di Ancona and the Archivio di Stato di Venezia and comprises the following material:

- List of entries and departures, Ufficio Sanità (public health center) - material connected to quarantine, crews, ship and commodity costs during quarantine and all issues of various centers of pests and other epidemics during the 18th century;

- Documents on ships entries and departures through the Arco di Traiano;

- A very interesting set of documents from the Cinque Savi alla Mercanzia in the Venetian Archives with consular letters. 
The third volume was printed in 2017 as a publication of the Department of History of the Faculty of Humanities and Social Sciences in Split, by Zrinka Podhraški Čizmek, Nikola Čolak〉s granddaughter as editor presenting another 3,927 documents from the Venetian and Ancona's state archives:

- Cinque Savi alla Mercanzia with consular letters from Ancona;

- A very interesting series of documents from the Scuole Piccole San Niccolò dei Marinari - the confraternity in which the benintrada and luminaria was paid by different people connected to maritime industry - thus, it is a very valuable material as it brings a whole series of Croatian, Italian and other nationes, captains, paroni (small shipowners), parcenevoli (co-owners and shipowners) and of course, ordinary sailors;

- Material regarding entries in Ancona through the Arco di Traiano.

It has to be emphasized that, during the 30 years of transcription of selected documents (1956-1985), Nikola Čolak analyzed all the families of captains, paroni and parcenevoli (Croats, Italians, Jews, Albanians, Greeks, Serbs and Montenegrins, English, French, Dutch, etc.); made their family trees from the processed material, where possible, following them through several generations throughout the $18^{\text {th }}$ century. The same can be said for the analysis of the variety of monies and measurement units used during the century and the import and export of merchandise through the eastern Adriatic ports, as evidenced by fifty published scientific papers as well as numerous boxes on these topics in his personal archival collection.

The fourth volume, with its ca. 4,000 entries, is directly bonded to earlier published volumes and further enriches the Croatian and international historiography with documents of rich Venetian archives.

The volume is accompanied by several scientific tools: a list of Italian toponomastics with referenced Croatian correspondences and Croatian toponomastics with Italian correlatives, Albanian toponomastics with Italian correspondences, instructions on pronunciation of Croatian and Albanian names, and abbreviations in Italian and Croatian texts.

At the end of the book there is an onomastic, toponomastic and analytical index - unavoidable tools in the treatment of the archival sources.

The list of displayed materials provides complete and consistent information on the documents that are provided in this book. For each individual document there are the following data: the number of a box from the Personal archival collection of Nikola Čolak (OF N.Č.) in the Croatian State Archives in Zagreb, followed by the file where the document is located. As far as the original context of the archival material is concerned, the designation of the archive from which it originates is given, as well as an archival collection to which it belongs, its name and the date to which it refers. 
Documents can be viewed in the following sections:

\begin{tabular}{|c|c|c|c|c|c|c|c|}
\hline $\begin{array}{l}\text { OF } \\
\text { N.Č. } \\
\text { Box }\end{array}$ & Folder & Archive & Collection & Name & From & To & $\begin{array}{c}\text { Doc. } \\
\text { no. }\end{array}$ \\
\hline 3338 & 5 & ASV & $\begin{array}{l}\text { Consoli dei } \\
\text { mercanti }\end{array}$ & Prove di fortuna & 1783 & 1794 & 1.293 \\
\hline 3338 & 1 & ASV & $\begin{array}{l}\text { Consiglio } \\
\text { dei X }\end{array}$ & Lettere dei Rettori - Zara & 1706 & 1741 & 3 \\
\hline $\begin{array}{l}33 \mathrm{~A} \\
38 \mathrm{~A}\end{array}$ & 2 & ASV & CSM & $\begin{array}{l}\text { Provveditor General da Mar } \\
\text { - Zara }\end{array}$ & 1698 & 1797 & 176 \\
\hline $\begin{array}{l}33 \mathrm{~A} \\
38 \mathrm{~A} 33\end{array}$ & 18 & ASV & $\begin{array}{l}\text { Provveditori } \\
\text { alla Sanità }\end{array}$ & $\begin{array}{l}\text { Epidemia Bovini, Lettere dei } \\
\text { Provveditori alla Sanità Zara } \\
\text { e Dalmazia, Contagio - Istria } \\
\text { e Dalmazia }\end{array}$ & 1727 & 1797 & 1.059 \\
\hline $\begin{array}{l}33 \mathrm{~A} \\
38 \mathrm{~A} 33 \\
38\end{array}$ & 6 & ASV & $\begin{array}{l}\text { Provveditori } \\
\text { alle Biave }\end{array}$ & $\begin{array}{l}\text { Biscotto spedito ai posti } \\
\text { militari in Dalmazia, } \\
\text { Istria e Levante. Relazioni } \\
\text { dei pubblici ministri. } \\
\text { Pieggiarie biscotto Levante e } \\
\text { Dalmazia. Registro ricerche, } \\
\text { commissioni, consegne per la } \\
\text { Dalmazia, Albania, Levante } \\
\end{array}$ & 1780 & 1797 & 1.194 \\
\hline 33 38A & 2 & ASV & $\begin{array}{l}\text { Provveditori } \\
\text { da Terra e da } \\
\text { Mar }\end{array}$ & Dalmazia: Sindici Inquisitori & 1748 & 1751 & 56 \\
\hline \begin{tabular}{|l|}
3338 \\
$38 \mathrm{~A}$ \\
\end{tabular} & 6 & ASV & Savio Cassier & $\begin{array}{l}\text { Documenti di spese, Bovi e } \\
\text { Beccarie }\end{array}$ & 1738 & 1797 & 112 \\
\hline $3338 \mathrm{~A}$ & 4 & ASV & Senato Rettori & Deliberazioni 1701-1711 & 1701 & 1711 & 57 \\
\hline $3338 \mathrm{~A}$ & 1 & ASV & $\begin{array}{l}\text { Patroni e } \\
\text { Provveditori } \\
\text { all'Arsenal }\end{array}$ & Catalogo delle navi & 1777 & 1797 & 7 \\
\hline $\begin{array}{l}33 \mathrm{~A} \\
38 \mathrm{~A} \\
38 \mathrm{~B}\end{array}$ & 4 & ASV & $\begin{array}{l}\text { Scuole Piccole } \\
\text { e Suffragi - } \\
\text { Indice } 217 \\
\text { Scuola di S. } \\
\text { Niccolò dei } \\
\text { Marineri in } \\
\text { S. Antonio di } \\
\text { Castello }\end{array}$ & $\begin{array}{l}\text { Indici e registri marinai } \\
\text { sudditi ed esteri, parcenevoli, } \\
\text { capitani e confratelli }\end{array}$ & 1720 & 1806 & $\begin{array}{c}4(= \\
3.289 \\
\text { entries })\end{array}$ \\
\hline \multirow[t]{2}{*}{3338} & 1 & ASV & $\begin{array}{l}\text { Tre Savi sopra } \\
\text { Conti }\end{array}$ & $\begin{array}{l}\text { Mandati, Costituti, Suppliche } \\
\text { e Risposte }\end{array}$ & 1764 & 1797 & 6 \\
\hline & 50 & & & & & & 4.027 \\
\hline
\end{tabular}


The first part contains materials from Archivio di Stato di Venezia (ASV) and it refers to the archival collections Consoli dei mercanti, Prove di fortuna, (1783-1794) and contains 1,293 documents in a total of 5 files, which are now in OF N.Č. 33 and 38. This series of documents brings very interesting stories and events related to Prove di fortuna where captains or paroni sought for compensation for accidents at sea: pirates' or corsairs' (privateers') attacks, arrembaggi of enemy ships in the Adriatic and beyond (by Russians, Americans, Tripolitans, etc.), damages to ships after storms or shipwrecks. These documents show incredible abundance of routes not only within the Adriatic, but also in the Mediterranean and even through the Strait of Gibraltar towards the Northern seas; at the same time, they show an efficient state apparatus that acknowledged damages not only to their own but also to foreign subjects. From these documents it is also evident that a big part of the trade belonged to Jewish merchants and parcenevoli.

The second part contains materials from ASV, from the archival collection Consiglio dei X, named Lettere dei Rettori - Zara (1706-1741) with 3 documents of one file from OF N.Č. 33 and 38, which show Zadar's rector who sent three cases to the Council of ten, to open the processes (cases occurred on the islands of Premuda, Vrgada and in the city of Zadar itself).

The third part contains materials from ASV, from the archival collection Cinque Savi alla Mercanzia (CSM), Provveditor General da Mar - Zara (1698-1797), bringing 176 documents from two files of N.Č. 33A and 38A. In this series of documents, various general governors (Provveditore generale) wrote from Zadar to Venice to the Cinque Savi alla Mercanzia on various trade related issues: shipwrecks, frauds (even by Venetian versus Turkish subjects), public money brought for the needs of the State, credit records for trade and merchandise transported from Zadar to Venice.

The fourth part contains materials from ASV, from the archival collection Provveditori alla Sanità and it refers to 18 different files connected to Epidemia Bovini, Lettere dei Provveditori alla Sanità Zara e Dalmazia, Contagio - Istria e Dalmazia (1727-1797). It brings 1.059 documents from OF N.Č. 33A, 38A, and 33. In this large group of documents there is a full set of descriptions of causes, dynamics and consequences of various plague epidemics, which have devastated not only Istria and Dalmatia but also the entire hinterland (Bosnia). They describe people and villages in those epidemic periods that could last for over a year. This was a major concern for Venice because the port of Zadar was the transit point for merchandize for the needs of Venice and the rest of La Serenissima. In the years of plague that had struck animals, we see all the modalities that Venice put into operation to contain the plague and ensure that the infected cattle be not spread out further across the Adriatic. The stories of people with whom they come in contact are really sad and illustrate the tragedy of those years.

The fifth part contains materials from ASV, from the archival collection Provveditori alle Biave with 6 different files regarding Biscotto spedito ai posti militari 
in Dalmazia, Istria e Levante, Relazioni dei pubblici ministri, Pieggiarie biscotto Levante e Dalmazia, Registro ricerche, commissioni, consegne per la Dalmazia, Albania, Levante (1780-1797), with a total of 1,194 documents from 6 files from OF N.Č. 33A, 38A, 33 and 38. In this series of documents, we find a variety of materials that show us how Provveditori alle Biave are concerned about purchasing not only grains but also finished products, such as pan biscotto for both ships and the stationary military crews on the eastern coast. We can see that Istria, the whole of Dalmatia and Albania Veneta are covered there. Indeed, there was a system of pieggiarie in operation which means borrowing money for a particular supply of food by ship, and the lists of creditors to the State were carefully guarded and billed.

The sixth part contains materials from ASV, from the archival collection Provveditori da Terra e da Mar and these are 2 files with materials on Dalmazia: Sindici Inquisitori (1748-1751), with 56 documents from OF N.Č. 33 and 38A. From these documents the everyday life of cities under responsibility of Sindici inquisitori was visible. It is about the cities of Zadar, Šibenik, Trogir, Split, Hvar, Kotor and Herceg-Novi. They were responsible for damages claimed by individuals in respect of various incidents (stay in quarantine, damage suffered by Turkish merchants, etc.), providing food for the army (with interesting data on problems with the Turks and the port of Durrës), the introduction of new agricultural cultures (up to procurement of plants and seeds), for savings plans at the local level (such as in Hvar or Zadar, where it also saves on "interpreters of lingua ilirica") and for the closure of the village trade and reinforcing trade in town etc.

The seventh part contains materials from ASV, from the archival collection Savio Cassier with 6 files regarding Documenti di spese, Bovi e Beccarie (1738-1797), with 112 documents from OF N.Č. 33, 38 and 38A. In this series of documents, there are accurate reports on the Venetian treasury business related to Dalmatia. There are lists of claims for reimbursement after shipwrecks (e.g. after robbery and beating of sailors by the Russians at Rhodes and so on), lists of insurance for various goods and ships, demands for money recovery due to various foreign scams of Venetian subjects, monthly pay lists for troops in Dalmatia and Albania, lists of quantities and prices of small and large cattle and the annual needs of La Serenissima.

The eight part contains materials from ASV, from the archival collection Senato Rettori with 4 different files on Deliberazioni (1701-1711) and contains 57 documents from OF N.Č. 33 and 38A: these were decrees that Senato Rettori proclaimed during the ten years (1701-1711) on one side to the Captain of the Gulf, and on the other regarding the extraordinary provision for Kotor and Albania. One of the priorities is safer navigation with regard to pirates and the supply of various military crews on the islands, as well as the supply of food and state money. The second major priority were the new-populated countries: it was necessary to divide them fairly, in order to get them more effectively taxed (for example, the case of various groups of Morlachs, who received land from both Venice and the Ottoman Empire). 
The ninth part contains materials from ASV, from the archival collection Patroni e Provveditori all'Arsenal under the title Catalogo delle navi-Arsenal Vini (17771797), contains 7 documents from one file in OF N.Č. 33 and 38A. In these several documents, it is determined which wines can be imported through the Arsenal (from Istria and Dalmatia) and which ratio is allowed in mixing wine (2/3) and water (1/3) for the preparation of the characteristic bevanda.

The tenth part contains materials from ASV, from the archival collection Scuole Piccole e Suffragi, Indice 217, Scuola di S. Niccolò dei Marineri in S. Antonio di Castello, and it includes only 6 documents from 4 files, with almost 3.000 subdocuments, titled Indici e registri Marinai sudditi ed esteri, Parcenevoli, Capitani e Confratelli (1720-1806) from OF N.Č. 33A, 38A and 38B. This list of members of the fraternity of S. Niccolò dei Marineri in the records of the paid benintrada for Scuola and the annual luminaria gives us an incredible overview of all sailors, pilgrims, captains not only of Venetian subjects but also of foreigners. They are a very valuable resource for the history of the people of the 18th century, just because they indicate the name, surname and the origin of each member of the Scuola.

The eleventh and the last part contains materials from ASV, from the archival collection Tre Savi sopra Conti under the title Mandati, Costituti, Suppliche e Risposte (1764-1797), bringing 6 documents from OF N.Č. 33 and 38. They include requests and resolutions related to various court processes. There are various requests and legal solutions by the prosecutor and lists of paid bails and court costs.

With this volume, we still remain within the Adriatic Sea with a special interest in the issues of La Serenissima in the hinterland of the eastern Adriatic coast and in the names of the participants in maritime traffic, whose number is ca. 3,000, counting only those from the list of Scuole Piccole S. Niccolò dei Marineri.

\section{Conclusion and perspectives}

We plan to publish the fourth volume in both print and digital format and to digitalize the first three volumes publishing them on the online platform of the project of the Croatian Maritime Regesta.

The next step will be to create a database for the existing volumes of the Croatian Maritime Regesta with about 20,000 published documents and thus to network it to other Mediterranean and maritime international projects that have been cross-referencing results of various researches for a number of years to get a more comprehensive and common database for the Mediterranean and world sailing through various historical periods.

It is our wish to continue working on this project and to publish consecutive volumes in the near future, not only in the paper but also in digital format, as we did for this $4^{\text {th }}$ volume. For such an extensive work, it will be necessary to form a team with 
several historians who would transcribe the rest of the documents that Colak collected during 40 years of research in Croatian and Italian archives (1956-1996). For such a big and important project, we will need the support of our entire scientific community.

A lot of people have helped us in the preparation and editing of this book. Primarily Dubravka Čolak who, also during her youth in Zadar, had retyped a part of the documents and with her efforts contributed to her father's work. Piergabriele Mancuso advised us about Venetian terms that we have not found in dictionaries and the overall reflections about creating a Croatian maritime database. Ante Gverić instructed us on issues regarding the archival profession. Josip Vrandečić and Marko Trogrlić advised us regarding our concerns about the sources. Stjepan Ćosić has supported this project since 2004, when, in capacity of the Director of the Croatian State Archives, received Nikola Čolak's personal archival collection. He has been even more involved since 2011, cooperating in the project restarting. Mateo Bratanić advised us on tips and perspectives regarding data processing within different major projects; Slaven Bertoša helped us with onomastic of the Northern Adriatic and Croatian names and Maria Lucia De Nicolò advised us on different maritime topics as well as topics of the Adriatic's daily life.

Being able to rely on experts not only in Croatia but also abroad is a great asset: it gives us hope for successful accomplishment of the great work ahead of us. 
